\title{
Association between the Sexual Activity and Acquired Immunity Markers in Women with Aids in a Brazilian Northeast County
}

\begin{abstract}
Pedro Mário Lemos da Silva1, Maria Bethânia da Costa Chein², Jacira do Nascimento Serra Maria Teresa Seabra4, Raimundo Antônio da Silva ${ }^{4}$, Luciane Maria Oliveira Brito ${ }^{4}$, Rita da Graça Carvallhal Frazão Corrêa4 , Flávia Helena Furtado Loureiro ${ }^{4}$, Ana Paula Matos Ferreira ${ }^{5}$, Claudia Regina de Andrade Arrais ${ }^{4}$, Antonia Iracilda e Silva Viana ${ }^{4}$
\end{abstract}

\section{Abstract}

Background: Acquired Immunodeficiency Syndrome (Aids) comes along the years promoting inversion of the relation men/women, committing mainly the productive and reproductive life phase women. The sexuality, inherent upon human being, has in the expression of satisfaction of the sexual performance the possibility of providing several benefits in the quality of life of people, and $C D 4^{+} \mathrm{T}$ - lymphocytes are the main marker of immunity of the women living with Aids. This study aims to show up the association between the CD4+ count and the sexual performance of women living with Aids in Imperatriz city.

Methods and Findings: cross-sectional analytical study, carried out in 10 months, selecting women using antiretroviral therapy at least six months, including those older than 18 , having sexual practice before having Aids, able to answer two questionnaires. Socio-demographic facts were recorded in own form, and sexual performance in the FSFI questionnaire. The sample based in 479 women, sampling error 5\%, confidence interval $95 \%$, alpha value $\leq 5 \%$, included 149 women. Chi-square test was used to evaluate the association between the variables. The larger FSFI score means and medians coincided with the highest means of $\mathrm{CD}^{+}{ }^{+} \mathrm{T}$ - lymphocyte count (Kruskal Wallis test, $\mathrm{p}=$ 0.0347 ), and a positive association between FSFI and the CD4+/CD8 ratio (Spearman test, $p=0.0264$ ), confirming the alternative hypothesis.

Conclusion: In this sample there was a positive association between sexual performance /sexual activity, with or without a condom, with CD4+ $\mathrm{T}$ - lymphocyte count and CD4+/CD8 ratio.
1 M. D. by the Post Graduate Program in Adult's and Child's health, UFMA

2 Post Graduate Program in Adult's and Child's health, UFMA

3 CEUMA University

4 Federal University of Maranão, UFMA

5 Nursery student.

\section{Contact information:}

Pedro Mário Lemos da Silva.

Gynecologist at the Adult Specialized Assistance Service for persons living with HIV in Imperatriz, Ma.

Address: Cel. Manoel Bandeira, 814, centro, 65900010 Imperatriz, Ma. Br. Tel: (99) 991283302

झ pedromario@uol.com.br

Keywords

Aids; Sexual Activity; Immunity. 


\section{Introduction}

The Acquired Immune Deficiency Syndrome (Aids ) is worldwide since the 80 s with the identification of the Human Immunodeficiency Virus (HIV) in 1983 by Luc Montagnier and his team, in France, ratified by Robert Gallo and colleagues in the United States of America a year later (Farthing, 1989). At that time Aids was associated with sexual activity as the only means, and, subsequently, as the most common means of HIV transmission, especially by sex between men. Later it was found that sexual orientation had no correlation with the syndrome, but the practice of unprotected sex as the means of transmission of the virus (Duarte, 2010). Though, in absolute numbers, the syndrome continues to be contracted more by men, the male/female ratio has gradually declined, since the 90 s, tending to feminization (Bastos, 2001), as well as impoverishment, heterosexualization and interiorization within Brazil (Faqueti et al., 2014).

Gender-dependent factors affect both susceptibility and severity to infections and autoimmunity and, considering the influence of sex hormones on the effector functions of different populations of immune cells, sexual activity should be considered when decisions are made and evaluated with respect to Aids control and treatment strategies (Markle, 2014). Thus this research aims to analyze the association between sexual activity and immunity, as expressed in CD4+ T-lymphocyte count, in order to identify benefits of this activity in women with Aids. This population was chosen due to the lack of data on female sexuality association with immunity. In this study, correlations between sexuality, Aids and women's immunity were assessed using two questionnaires (a validated one for investigation of female sexual activity, The Female Sexual Function Index - FSFI, and other one with sociodemographic and behavioral variables), and comparison of CD4 ${ }^{+}$ T- lymphocyte count with the result of the domains of the FSFI.

\section{Theoretical Background}

Sexuality is a noun derived from sex (sexus, Latin), whose etymology indicates particular conformation that distinguishes male from female, animals and vegetables (Gewehr e Hetkowski, 2001). Its understanding is so important that integrates the concept of quality of life. It includes the physical, mental, social and spiritual dimensions, as a subjective and multidimensional concept, which run through sexual activity and pleasure in all these dimensions, particularly the physical and psychological ones (Rohde, 2014).

Kinsey et al were the first who studied sexuality systematically. They presented, through direct interrogation techniques (16 392 persons interviewed: 8,603 men and 7,789 women), several epidemiological reports on sexual behavior in the United States in the period 1938-1953. However the anatomical and functional response to sexual stimulation was first assessed, in laboratory, by William Howell Masters and Virginia Johnson Eshelman (Masters and Johnson). These authors observed 10,000 sex intercourses of 694 volunteers over an 11 year period in the United States (382 women), using footage in colors and laboratory studies of the physical and physiological aspects of sex, which resulted in the publication of Human Sexual Response, a book (Sena, 2012).

Before Masters and Johnson the study of human sexuality was restricted to reproductive function, however sexual behavior should not be perceived as a single action, purely psychological (psychologism), sociological (sociologism), biological (biologism) (Cavalcanti \& Cavalcanti, 2012).

Among other findings, they pointed out that the physiological response to erotic stimuli were not restricted to the genitals, but widespread throughout the body, thus all of it would be eroticiseable depending on the particular conditions of each person in interaction with ecological variables (motivator, type and intensity of erotic stimulation, etc.) (Sena, 2010). 
Considering the skin the largest sex organ in extension(Cavalcanti \& Cavalcanti, 2012), it is the organ which transforms physical stimuli into chemical communicators and psychological states, therefore neurotransmitters and nerves carry the message, sent through touch, up to the central nervous system and this models the state of the skin by means of their own neurotransmitters (nerves and cutaneous immune cells), Azambuja (2005) apud (Costeira, 2008), and the skin contact of any part of the body generates some kind of pleasure (Mattos, 2013).

Shere Hite is a feminist who defended the right of the female orgasm as author of The Hite Report (Female Sexuality Report) in 1976, in the US, using anonymous written questionnaire about intimate experiences, sent by readers of magazines and newsletters, released the extraordinary clitoral orgasmic capacity and the emphasis on masturbation as a source of sexual satisfaction, as reported by Kinsey (Sena, 2012).

Sexuality is manifested by feelings related to the fact of being male or female and the ways of expression of these feelings, involving sexual fantasies, masturbation, sexual contact and interpersonal relationships (Vitiello, 1997). It is a systemic complex that includes clinical, hormonal, psychological, cultural, anthropological, social and behavioral aspects, among others, that are combined (Zampieri, 2004). Unlike other mammals, sexuality generates pleasure for human beings, regardless of reproductive cycle, and their biologically homeostasis is coordinated by the nervous, endocrine and circulatory systems (Marques, 2008).

According to $\mathrm{WHO}$, sexuality is an energy that motivates us to seek love, contact, warmth and inti- macy; forming part of the way we feel, move, touch and are touched; it is to be sensual and at the same time sexual; it influences thoughts, feelings, actions and interactions and, therefore, also influences our physical and mental health(Pontes, 2011).

For the United Nations Educational, Scientific and Cultural Organization (UNESCO, 2010):

"Sexuality is a fundamental aspect of human life: It has physical, psychological, spiritual, social, economic, political and cultural dimensions. Sexuality cannot be understood without reference to gender. Diversity is a key feature of sexuality. The rules governing sexual behavior differ widely between cultures and within a same culture. Certain behaviors are seen as acceptable and desirable while others are considered unacceptable. This does not mean that these behaviors do not occur, or that should be excluded from consideration in the context of sexuality education. "

There's neurofunctional similarity between the two sexes; vasocongestion determines penile erection and vaginal lubrication and distension. Both male and female have various patterns of sexual response well characterized reflecting a unitary, sequential, continuous and organized process: appetite, arousal, orgasm and relaxation (Cavalcanti \& Cavalcanti, 2012) (Table 1).

However, unlike the men, the feminine sexual response is circular, starting with spontaneous or motivated desire, followed by excitement, followed by satisfaction, with or without orgasm, and can restart the cycle or not (Basson, 2005).

The appetence or desire, willingness to practice sexual intercourse by sensory stimulation and/or erotic experiences and/or fantasies, described by

Table 1. Stages of human sexual response; modified adaptation of (Cavalcanti \& Cavalcanti, 2012).

\begin{tabular}{l|c|c|c|c|}
\hline \multicolumn{1}{|c|}{ Cavalcanti \& Cavalcanti } & Havelock Ellis & Helen Singer Kaplan & Masters and Johnson & Rosimary Basson \\
\hline $\begin{array}{l}\text { Appetence } \\
\text { Arousal }\end{array}$ & Tumescence & Genital vasocongestion & Arousal + plateau & Desire \\
\hline $\begin{array}{l}\text { Orgasm } \\
\text { Relaxation }\end{array}$ & Orgasmic reaction & Orgasm & Orgasm \\
\hline
\end{tabular}


Table 2. Organic manifestations of sexual response, adapted from (Cavalcanti \& Cavalcanti, 2012).

\begin{tabular}{l|l}
\multicolumn{1}{c|}{$\begin{array}{c}\text { Sexual Response } \\
\text { Extragenital vasocongestion }\end{array}$} & $\begin{array}{l}\text { Maculo-papillary erythema, areolar tumescence, expansion of vascularization and volume of } \\
\text { the breasts. }\end{array}$ \\
Genital vasocongestion & $\begin{array}{l}\text { Labia majora flatten and tune up (nulliparous), swell(multiparous. Labia minora double or } \\
\text { triple, protrude out: the vagina length increases by } 1 \mathrm{~cm} . \text { Enlargement of the clitoris. Swelling } \\
\text { of the vaginal bulbs, uterus and uterine ligaments. Vagina: lubrication, anterior-posterior } \\
\text { stretching }(+/-3 \mathrm{~cm}), \text { lateral expansion of the upper } 2 / 3(+/-5 \mathrm{~cm}) \text { resulting in uterine elevation. } \\
\text { Formation of the orgasmic platform. }\end{array}$ \\
\hline Extragenital myotonia & $\begin{array}{l}\text { Erection of the nipples. Contractions and voluntary and involuntary spasms of mimic muscles, } \\
\text { sternocleidomastoid, intercostals, rectus abdominis, buttocks and limbs. Perspiration, } \\
\text { hyperventilation and tachycardia. }\end{array}$ \\
\hline Genital myotonia & $\begin{array}{l}\text { Retraction of the clitoris. Contraction of bulbovaginal muscles. Shortening of the uterine } \\
\text { ligaments. Uterine contractions. Contractions of orgasmic platform. }\end{array}$
\end{tabular}

Kaplan in 1977, is a stage of subjective manifestation, the others have objective and subjective components: The excitement subjectively shows the growing sense of desire, and myotonic reaction plus vasocongestion objectively, with competition between parasympathetic and sympathetic systems, with sympathetic predominance, it corresponds to vaginal lubrication and training of orgasmic platform, and penile erection. In orgasm occurs subjectively feeling of pleasure, loss of acuity of the senses, shutdown sense the external environment, and objectively it presents reflex muscle contractions (3 to 15 rhythmic contractions of orgasmic platform, with an interval of 0.8 seconds), with predominance of the sympathetic system. Relaxation is characterized subjectively by sense of relief and fatigue, and sensory standards, and objectively by vascular decongestion and muscle relaxation, with parasympathetic system predominance (Marques, 2008);(Cavalcanti \& Cavalcanti, 2012).

A study conducted by Davey Smith, Frankel (1979-1983), and Yarnell (1997) on the relationship between the frequency of orgasms and mortality in the United Kingdom, whose study, in ten years of follow up, they found that the risk of mortality was $50 \%$ lower in men who had two or more orgasms per week than those who had less than once per month. And even when evaluated other variables such as age, social class, and smoking, a large and significant inverse relationship between the frequency of orgasms and risk of death was found. They concluded that sexual activity seems to have a protective effect on men's health (Komisaruk, 2006); (Brody, 2010).

Sexual act is summed up in a binary compound $f-F$ (friction-Fantasy), more fantasy than friction. The participation of organic structure is important for sexual response, to which the biological soundness favors, but does not determine a perfect answer because the emotional is so important, making the sexual act a result of biopsychic unit participation. However it is culture that defines sexual stimuli, therefore in our culture women are more sensitive to tactile stimuli, hugs, kisses, caresses (somatic), recall erotic experiences or creating erotic fantasies (psychogenic). Physiologically these stimuli result in organic response (Table 2 ) resulting from superficial and deep vasocongestion, and specific and generalized myotonia (Cavalcanti \& Cavalcanti, 2012).

The brain is the most important sexual organ of the human being, as it controls the sexual behavior, whose brain regions involved has been identified by the following methods: axoplasmatic transport (transport of substances within neurons), neuroimaging (Computed Tomography - CT and Magnetic Resonance Imaging - MRI), regional cerebral blood 
flow, positron emission tomography (PET), positron emission photons (SPECT), functional MRI, EEG, evoked potentials, magnetoencephalography. The major brain regions involved in the sexual response are the limbic system, hypothalamus and midbrain (Cavalcanti \& Cavalcanti, 2012).

Sexuality is intrinsically linked with the female immunity considering that in a literature review of 61 articles published in the SciELO and Medline/ PubMed databases, sex steroids also modulate immune responses; while estrogens in low doses seem to stimulate, the progesterone and androgen tend to suppress. Lymphocyte subpopulations are endowed with estrogen receptors and their inhibition or blockage can alter production of immunoregulatory factors, reducing them in such a way as to limit the expression of antigens and decrease the capacity of lymphocytes to react with other cells (Medeiros, 2007).

A study indicates vibrators as accessories in the treatment of female sexual dysfunction; they are associated with health-promoting behaviors (data showed that vibrators users were significantly more engaged to two specific health-promoting behaviors when compared to non -users: they underwent gynecological examination, and carefully observed their genitals in the last year and last month respectively), and they are rarely associated with any side effects as a result of its use (Herbenick, 2009).

A study comparing the sexual activity to physical activity, found that orgasm is mentally and physically as beneficial as an eight kilometers of racing thanks to increased heart rate, which is equivalent to a vigorous aerobic exercise as well as the release of endorphins following orgasm. This experience, physically and mentally pleasant, is primarily chemical caused by releasing a cocktail of neurotransmitters through the nervous system: two catecholamines (noradrenaline and dopamine), and indoleamine and serotonin. Serotonin and dopamine release endorphins (similar structure to that of morphines, they are pain relieving) in the brain that are pleasure stimulating, and provide a numbing, gently narcotic and reassuring sensation, explaining thus the eternal attraction the orgasm exercises on the human species, as well as the sense of comfort and temporary disconnection of reality it offeres, whose French description is "La petite mort" (Margolis, 2006).

Endorphins act as classical hormones in the pituitary; and they act as neurotransmitters or neuromodulators in the central nervous system, where they are directly responsible for the mediation of pain, perception, and emotional sensory information. The endogenous opioids, particularly b-endorphin, can modulate the natural immunity by increasing the activity of natural killer (NK) cells. The chronic administration of b-endorphins increases natural immunity, possibly through the " $m$ " and " $d$ " opioid receptors. The b-endorphin and ACTH are secreted by the anterior pituitary in response to exercise. The mild form of exercise performed are associated with increased activity of NK cells, lymphocyte subpopulation that have cytotoxic effect on virus-infected cells and some varieties of tumor cells, and reduce infections of the upper respiratory tract. However Jonsdottir et al., 1997, reported that clinical studies showed that exhaustive exercise increased the incidence of infections (Hayashida et al., 2003).

Some impact of exercise on the immune system of the elderly, who show a decrease in the number and function of $T$ cells and changes in composition of its subpopulations, as occurs in Aids, is observed in studies by Nieman et al (1993) which demonstrated that active highly conditioned women had an aerobic power, $67 \%$ higher, proliferative response of lymphocytes and fitohemoglutinina (PHA), 56 \% higher, and also an activity of NK cells, 54\% greater than sedentary (Santos, 2010).

On the other hand we continuously live with all kinds of microorganisms (viruses, fungi, bacteria, protozoa), and infection with any of these leaves permanent damage in our bodies as a result of combating microorganisms done by our immune system, 
constituted by cells and molecules that promote immunity, specializing in defending the body against the presence of foreign substances, independently the physiological or pathological consequences of this immune response.(Abbas, 2011).

Functionally, the immune system is divided in innate (tries to prevent the development of infection) and adaptive one (attempts to eradicate the infection, producing a specific response against each microorganism, and develop antimicrorganism-specific memory capable of preventing the development of new infection by the same agent). The skin, enzymes (lysozyme, defensins and phospholipases), body temperature, gastric acidity, collectin and TL receptor (cytoplasmic membrane receptor), complement system (circulating activated protein antibodies, or contact with the infectious agent, the lectin) phagocytes (macrophages, monocytes, neutrophils), NK cells and interferon are elements of the innate immune system (Table 3), lymphocytes mediate adaptive immunity. The immune cells are present in all tissues, especially circulating in the blood and lymph, and agglomerated in lymphoid organs.(Roitt, 1989); (Soares, 2014).

Acording to Abbas (2011) and Soares (2014) adaptive or acquired immunity is mediated by lym- phocytes, principal cells of the humoral and cellular immunity, the only cells that express antigen receptors with the same specialty in its clones, therefore there are millions of lymphocyte clones able to recognize and respond to millions of foreign antigens.

For both authors a healthy adult has about 500 trillion lymphocytes (2\% are in the blood, $10 \%$ in bone marrow, 15\% in mucosal lymphoid tissues of the gastrointestinal and respiratory tracts, and $65 \%$ in lymphoid organs), among them stand out B lymphocytes (antibody-producers, when activated by CD4+ ${ }^{+}$- lymphocytes), CD4 ${ }^{+}$T- lymphocytes, helper lymphocytes, promote the differentiation of B lymphocytes to plasmocytes (humoral immunity), activate macrophages (cell-mediated immunity) and stimulate inflammatory process with the release of cytokines, activate CD8 T- lymphocytes, or cytotoxic lymphocytes, that destroy cells infected by viruses or intracellular bacteria and promote allograft rejection, and NK cells which promote the cytotoxic destruction of virus infected cells or damaged cells (innate immunity).

The virgin lymphocytes (which never found its corresponding antigen) normally die after 1 to 3 months, if they don't recognize an antigen, but the memory cells can survive for months or years

Table 3. Main cells of the innate immune system; adapted from (Roitt, 1989); (Soares, 2014).

\begin{tabular}{|c|c|c|}
\hline Célls & Features & Functions \\
\hline Neutrophils & $\begin{array}{l}\text { Most abundant circulating polymorphonu- } \\
\text { clear Phagocyte cells undergo apoptosis unless } \\
\text { recruited to an inflammatory site within } 6 \text { hours. }\end{array}$ & Identify, engulf and destroy micro- organisms. \\
\hline Monocytes & $\begin{array}{l}\text { Mononuclear phagocytes, mature in tissues with } \\
\text { the name of macrophages (microglia in the CNS, } \\
\text { Kupffer cells in liver, alveolar macrophages in the } \\
\text { lungs). }\end{array}$ & $\begin{array}{l}\text { Identify, phagocyte and destroy microorganisms } \\
\text { phagocyte apoptotic neutrophils, present } \\
\text { antigens (APC) to CD4+ T lymphocytes, } \\
\text { activating them. }\end{array}$ \\
\hline $\begin{array}{l}\text { Mast cells, eosinophils } \\
\text { and basophils }\end{array}$ & $\begin{array}{l}\text { They have granules in the cytoplasm completed } \\
\text { by inflammatory and antimicrobial mediators. }\end{array}$ & $\begin{array}{l}\text { Immune response to helminth and allergic } \\
\text { diseases. }\end{array}$ \\
\hline $\begin{array}{l}\text { Antigen presenting cells } \\
\text { (APC) }\end{array}$ & Nucleated cells. & $\begin{array}{l}\text { Present antigens to CD8-T lymphocytes (they } \\
\text { recognize the antigen, are activated and kill the } \\
\text { cells). }\end{array}$ \\
\hline Dendritic cells & APC & Activate naive T lymphocytes and B lymphocyte \\
\hline
\end{tabular}


without being stimulated by antigen. T cells have proteins on their cell membranes that characterize, those are cluster of differentiation markers $=C D$, which are numbered, among which the most important for this study are CD4 ${ }^{+}$and CD8 (Abbas, 2011); (Soares, 2014).

The CD4 ${ }^{+} \mathrm{T}$ - lymphocytes are the main target of HIV, etiological agent of Aids, and their number decreases as the disease progresses. The HIV virus adheres to the cytoplasmic membrane of the host cell enzymes and injects its RNA into the host cytoplasm, transforms its RNA into DNA analogue, integrates its DNA into the host cell DNA and encapsulates their virions, which once released will infect new lymphocytes, exercising the viral reproductive cycle. When the body can not hold the HIV reproductive cycle, and CD4 ${ }^{+} \mathrm{T}$ - lymphocytes decrease below 350/mm3 of blood, the virus host can begin to develop diseases caused by other parasites micro -organisms, called opportunistic, which characterize Aids. This phase of immune weakness favors the development of other diseases and the very spread of HIV in the body, featuring this infection as a syndrome whose most common symptoms are fever, diarrhea, night sweats and weight loss (Brasil, 2013).

The count of $\mathrm{CD}^{+}{ }^{+} \mathrm{T}$ lymphocytes, CD4 ${ }^{+} / \mathrm{CD} 8$ ratio and viral load (VL) are used to assess the progress and prognosis of the disease and the effectiveness of the treatment and evaluate the state of the immune system, therefore the risk of debilitating complications such as infections. As their absolute counts vary daily it is useful to determine CD4+ Tlymphocytes count compared to other types of lymphocytes. CD4 ${ }^{+}$T-cells, CD8 T - cells and VL counts are requested when the diagnosis of HIV is done as part of a basal evaluation, should be repeated about 2 to 8 weeks after the start or after the modification of treatment, and every three or four months while treatment is maintained. Medicines produced up to date against HIV cannot destroy it, but hinder its action by inhibiting the HIV enzymes, slowing or preventing its multiplication or accession of the virus to lymphocytes (Brasil, 2013).
In about 26 countries between 2001 and 2012, HIV infection has decreased by around $50 \%$ or more among adults and adolescents, but other countries have not achieved the same, which reinforces the importance of intensifying prevention. Circumcision of $80 \%$ of all adult men in countries of high HIV prevalence and low prevalence of circumcised men by 2015, should prevent one in five new cases of HIV infection by 2025 (UNAids, 2012).

However the Aids epidemic in Brazil has grown among youth and adolescents. The incidence rate (number of cases per 100,000 inhabitants) aged 1524 years of age was 9.3 in 2001, rose to 10.9 in 2011. And the evolution of Aids trends for impoverishment, heterosexualization, feminization and interiorization (Brasil, 2013).

Feminization of Aids in Brazil, from the 90's, is explained by the greater biological vulnerability of women to HIV infection, considering the surface of the vaginal mucosa exposed to semen is relatively large, semen has a higher concentration of HIV than vaginal secretion, greater directionality and dissemination of semen ejaculated in the vaginal fluid, Sexually Transmitted Inections (STI's) are often more asymptomatic in women than in men, the local inflammation and micro-injuries caused by their etiological agents weaken the natural barriers to HIV infection, and early onset of sexual activity (pre-puberty and puberty) as a result of the immaturity of the genital tract, causing a further weakening to HIV infection (Bastos, 2001).

The vulnerability of a particular group to HIV infection and/or disease, is the result of several features of political, economioc and sociocultural contexts that increase or decrease the individual risk. In qualitative research, with 12 women over the age of 18 years, different educational levels, race and religion, interviewed women recognized vulnerability factors on the other ones and realized the risk of others acquire STI/HIV, but they didn't consider themselves in risk (Silva, 2009).

Girls and women are particularly vulnerable to HIV 
infection due to a combination of biological factors and gender inequalities, particularly in cultures that limit knowledge about HIV, the ability to protect themselves and negotiate safer sex (OMS, 2011).

Vulnerability to HIV increases with traumatic sexual intercourse, such as coercive sex, or when there is female genital mutilation, characterized by dyspareunia, lacerations and inflammation (Ghosh et al., 2013).

\section{Method}

\section{Type of study}

Analytical Cross-sectional Study.

\section{Time and place of study}

Data collection was performed at the Specialized Assistance Service (adult SAS), Division of Sexually Transmitted Infections (STI/Aids) of the Health Department of the city of Imperatriz - Ma., from March to December 2014. Imperatriz is a western city of Maranhão, 639 km far from the capital, São Luís, and stands as junction to cities in the southwestern Maranhao, northern Tocantins and southern Pará. It is $257 \mathrm{~km}$ far from Araguaina - TO, $644 \mathrm{~km}$ far from Palmas - TO, and 608 km far from Belém PA. It is linked to the state of Tocantins by Don Felipe Gregori and Estreito bridges, both built on the Tocantins River that separates the states of Maranhão and Tocantins. It has intense migratory flow overland through the Belem-Brasilia highway which crosses it from north to south, via river, across the Tocantins River, and by airplanes, which connect it to the world through the TAM, GOL, AZUL and SETE airlines. It is the second university center of Maranhão with 3 public universities and five private ones, as well as a municipal theater and multiplex cinema. It is considered the second largest economic, political, cultural and population center of the state of Maranhão. Its economy comes from the agriculture sector, livestock, vegetable extraction, trade, industry and services. As a result of this rap- id and significant development has received many titles over the years: Tocantins Princess, Portal of the Amazon, Brazilian Capital of Energy and National Integration Metropolis. (Imperatriz, 2015).

\section{Sample}

We selected 227 women, the Unified Health System (SUS) users, followed clinically in Imperatriz SAS, with or over 18 years of age, from March to December 2014, with confirmed clinical diagnosis of HIV infection and treated with Antiretroviral Therapy regimen (ART), registered in Logistics Management System of Medicines (SICLOM) for at least six months before the data collection. We included those over 18 who reported sexual activity before Aids diagnosis, able to communicate in Portuguese, without any cognitive impairment, who totaled 149. All were invited to participate in the study giving their consent signing the Informed Consent Form (ICF), detailed in Appendix B. They were excluded those who did not complete all "Sexual Function Index Female" (FSFI) questionnaire, those who had had any infection, surgery, or immunization in the three months preceding the completion of the FSFI and sociodemographic questionnaire, and those sexually inactive within two months prior to the completion of the FSFI, totaling 78. There was no loss.

\section{Sample characterization}

The women living with Aids, in the sample, prevailed those: between 31 and 41 years old (47.7\%), whose mean age was 38, standard deviation (SD) of 9.1 years, brown (56,3\%), with 9-12 years of school education (33.5\%), housewives (50.3\%), Catholic (53\%), married (39.6\%), living with a partner (62.4\%), who gave birth at least once (91.2\%), had at least one living child (88,6\%), sedentary women (67.1\%), who slept six or more hours a day (87.9\%), not using drugs (smoking/alcohol) (72.5\%), had stable sexual partner (81.9\%) always used condoms (69.1\%), practiced by 1 intercourse per month (67.8\%), and who practiced satisfactory sexual activities to themselves in more than $50 \%$ of sexual activity (57.7\%) (Table 4 ). 
Table 4. Some socio-demographic and reproductive variables, lifestyle and sexual behavior characteristics of women with Aids . Imperatriz (MA) - BR. 2014

\begin{tabular}{|c|c|}
\hline Variables & n (\%) \\
\hline \multicolumn{2}{|l|}{ Age (years old) } \\
\hline $18-30$ & $30(20.1)$ \\
\hline $31-41$ & $71(47.7)$ \\
\hline $42-53$ & $35(23.5)$ \\
\hline $54-65$ & $13(8.7)$ \\
\hline \multicolumn{2}{|l|}{ Skin color } \\
\hline Brown & $84(56.3)$ \\
\hline White & $36(24.2)$ \\
\hline Black & $29(19.5)$ \\
\hline \multicolumn{2}{|l|}{ Years of schooling } \\
\hline 1 a 4 & $40(26.9)$ \\
\hline 5 a 8 & $48(32.2)$ \\
\hline 9 a 12 & $50(33.5)$ \\
\hline Mais de 12 & $11(7.4)$ \\
\hline \multicolumn{2}{|l|}{ Ocupation } \\
\hline Hosewife & $75(50.3)$ \\
\hline Autonomus & $10(6.7)$ \\
\hline Not autonomus & $64(43)$ \\
\hline \multicolumn{2}{|l|}{ Monthly income (MW)* } \\
\hline Not informed & $3(2)$ \\
\hline Up to 1 & $107(71.9)$ \\
\hline Between 2 and 3 & $37(24.8)$ \\
\hline More than 3 & $2(1.3)$ \\
\hline \multicolumn{2}{|l|}{ Religion } \\
\hline Catholic & $79(53)$ \\
\hline Evangelical & $64(43)$ \\
\hline Others & $6(4)$ \\
\hline \multicolumn{2}{|l|}{ Marital status } \\
\hline Single & $54(36.2)$ \\
\hline Married & $59(39.6)$ \\
\hline Divorced & $21(14.1)$ \\
\hline Widowed & $15(10.1)$ \\
\hline \multicolumn{2}{|l|}{ Live with a partner } \\
\hline Yes & $93(62.4)$ \\
\hline No & $56(37.6)$ \\
\hline \multicolumn{2}{|l|}{ No. of pregnancies } \\
\hline None & $13(8.8)$ \\
\hline Between 1 and 2 & $54(36.2)$ \\
\hline Between 3 and 4 & $55(36.9)$ \\
\hline More than 4 & $27(18.1)$ \\
\hline
\end{tabular}

\begin{tabular}{|c|c|}
\hline Variables & n (\%) \\
\hline \multicolumn{2}{|l|}{ Live children } \\
\hline Do not apply & $13(8.7)$ \\
\hline None & $4(2.7)$ \\
\hline Between 1 and 2 & $65(43.6)$ \\
\hline Between 3 and 4 & $56(37.6)$ \\
\hline More than 4 & $11(7.4)$ \\
\hline \multicolumn{2}{|l|}{ Exercises } \\
\hline None & $100(67.1)$ \\
\hline$\geq 3 \times$ week & $36(24.2)$ \\
\hline$<3 \times$ week & $13(8.7)$ \\
\hline \multicolumn{2}{|l|}{ Hours per day of sleeping } \\
\hline$\geq 6$ & $131(87.9)$ \\
\hline$<6$ & $18(12.1)$ \\
\hline \multicolumn{2}{|l|}{ Drugs** } \\
\hline Don't use & $108(72.5)$ \\
\hline Cigarettes & $41(27.5)$ \\
\hline Alcohol & $11(7.4)$ \\
\hline Others & $2(1.3)$ \\
\hline \multicolumn{2}{|l|}{ Sexual partner } \\
\hline Stable & $122(81.9)$ \\
\hline Unstabel & $27(18.1)$ \\
\hline \multicolumn{2}{|l|}{ Condom use } \\
\hline Always & $103(69.1)$ \\
\hline Sometimes & $29(19.5)$ \\
\hline Notime & $17(11.4)$ \\
\hline Alcohol & $11(7.4)$ \\
\hline \multicolumn{2}{|c|}{ Maximum frequency of sexual activity per month } \\
\hline Do not inform & $3(2)$ \\
\hline$\leq 1$ & $101(67.8)$ \\
\hline$>1 \mathrm{e} \leq 2$ & $10(6.7)$ \\
\hline$\leq 3$ & $4(2.7)$ \\
\hline$\leq 4$ & $15(10.1)$ \\
\hline$\geq 5$ & $16(10.7)$ \\
\hline \multicolumn{2}{|c|}{ Own satisfactory sexual activity frequency } \\
\hline None & $8(5.3)$ \\
\hline$<50 \%$ & $33(22.2)$ \\
\hline $50 \%$ & $22(14.8)$ \\
\hline$>50 \%$ & $27(18.1)$ \\
\hline All & $59(39.6)$ \\
\hline Total & $149(100)$ \\
\hline *: MW: minimum W & $\begin{array}{l}\text { e than one drug } \\
\text { simultaneously }\end{array}$ \\
\hline
\end{tabular}




\section{Sample size calculation}

The calculated sample of 214 women, according to the sampling Calculator Sample Size Calculator by Raosoft, Inc, and Santos (2014) based on the following estimates: Total number of women enrolled in the Logistics Management System of Medicines, Imperatriz city (479), sampling error (5\%), confidence interval $(95 \%)$, distribution $(50 \%)$, resulting a sample of 214 women.

\section{Instrument of data collection and evaluation}

The women in the sample answered two questionnaires: the first, semi-structured, with 20 questions (13 closed), was an interview on sociodemographic variables (age, race, education, parity, family income, occupation, marital status, sexual activity, alcohol consumption, smoking, physical activity), clinical factors related to co-morbidities and surgical procedures, with space for annotation of antiretroviral treatment regimen (ART) and test results of CD4 ${ }^{+}$and CD8 T lymphocyte counts. (Appendix A), the second was a self-administered structured questionnaire in 19 closed questions, responded after the first, which proposed to assess female sexual response in six areas, in the past 4 weeks: sexual desire, sexual arousal, vaginal lubrication, orgasm, sexual satisfaction and pain. It was validated for use in Portuguese, originally known as Female Sexual Function Index (FSFI) (Annex 1). For each question there was a response pattern which options were scored 0-5 increasingly for the presence of the challenged function. Only in questions about the pain score was defined in reverse. A total score was displayed at the end of the application, the result of the sum of the scores for each domain multiplied by a factor that homogenized the influence of each domain in the total score. To facilitate the multiplications all multipliers were multiplied by 10 , so the minimum score became 12 and the maximum one 360. For evaluating FSFI here are the following scores (Table 5): (Rosen et al., 2000); (Pacagnella, 2009).

To perform the data collection, a pilot study was carried out with 12 women to test the feasibility of the two questionnaires that would be used. The questionnaires were applied individually in women in the collective counseling room by the researcher as they waited to collect blood for performing $\mathrm{CD}^{+}{ }^{+} \mathrm{T}$ - lymphocyte counts and viral load (VL) for evaluation of their immunity, clinical care and receipt of ART and other drugs listed in the basic pharmacy. The pilot study showed that patients were unaware of T-lymphocytes and VL, not even its importance, and if approximately $50 \%$ of them received their food baskets and medicines, would not expect the clinic consultation, or blood collection. Some received medication because it was a condition of receiving food baskets and passes for buses, but did not bother to use them properly and/or regularly. After a three-week pilot study, the strategy was changed to motivate the women

Table 5. Scores assessment of the Female Sexual Function Index.

\begin{tabular}{|l|c|c|c|c|c|}
\hline \multicolumn{1}{|c|}{ Domain } & Questions & Scores & Multiplier factor & Minimum score & Maximum score \\
\hline Desire & 1,2 & $1-5$ & 0.6 & 1.2 & 6.0 \\
\hline Arousal & $3,4,5,6$ & $0-5$ & 0.3 & 0 & 6.0 \\
\hline Lubrication & $7,8,9,10$ & $0-5$ & 0.3 & 0 & 6.0 \\
\hline Orgasm & $11,12,13$ & $0-5$ & 0.4 & 0 & 6.0 \\
\hline Satisfaction & $14,15,16$ & $1-5$ & 0.4 & 0 & 6.0 \\
\hline Pain & $17,18,19$ & $0-5$ & 0.4 & 0 & 6.0 \\
\hline Total & & & & 1.2 & 36 \\
\hline
\end{tabular}


to participate in the research and provide them with greater autonomy about their treatment. As well as all previously scheduled patients, 10 and 20 , were gathered in the living room of the collective advice, waiting for the blood collection for $\mathrm{CD}^{+}{ }^{+} \mathrm{T}$ - lymphocyte count, receiving the basic food basket/bus passes and medical care, an informative - educational intervention was performed. At that time women were asked about what were lymphocytes, their importance and difference between them and $V L$, and why did the exam. As they did not know, the explanation was given them by comparing the $\mathrm{CD}^{+} \mathrm{T}$ - lymphocytes to Army soldiers and the body to the barracks and other comparisons of popular everyday. Completing the researcher talked about the research of Davey, Smith, Frankel (1979-1983), and Yarnell (1997), apud (Brody, 2010) and (Komisaruk, 2006), then he wondered if women were equal to men, as the answer was no, they were asked if they would like to participate in the study whose objective was to investigate whether the sexual activity had significance or relationship to the improvement (or not) of immunity. Blood collection for $\mathrm{CD}^{+}{ }^{+} \mathrm{T}$ - lymphocyte count was carried out in a room next to the collective advice, attached to the laboratory of SAS, on Mondays and Thursdays, by nursing technicians trained by biochemists who performed the count of lymphocytes by flow cytometry method, trained by the company that manufactures the material necessary to do so (machines and kits for the exam) in comodata arrangements with the Health Ministry of Brazil

\section{Processing and statistical analysis}

Data were tabulated in Microsoft Office Excel@ software, version 2010 (Microsoft Corporation, Redmond, United States of America) and expressed in tables, as absolute and relative frequencies, the categorical variables, and as mean, standard deviation, amplitude (parametric) and median (nonparametric), the continuous ones. The CD4 ${ }^{+}$T-lymphocyte cell count was stratified into quartiles, like the average score of the questionnaire Female Sexual Function Index (FSFI), then the quartiles were compared using Kruskal Wallis test. The Spearman correlation between the score of the FSFI and the lymphocyte count $\left(\mathrm{CD}^{+}{ }^{+}, \mathrm{CD} 8\right.$ and $\left.\mathrm{CD} 4 / \mathrm{CD} 8\right)$ was drawn. The parametria of the variables was performed by the Shapiro-Wilk test. All statistical analysis was performed using Stata (12.0) $®$ (Stata Corp LP, College Station, Texas, United States of America) and the alpha significance level of less than $5 \%$ was considered.

\section{Ethical aspects}

Data collection started after approval and issuance of the consolidated written opinions by the Research Ethics Committee, look 19020213.4.0000.5086, according to CNS Resolution No. 466 of 12/12/2012. Before answering the questionnaires each subject received two copies of the ICF, which was read by the researcher, to sign.

\section{Results}

The sample consisted of 149 women, their epidemiological profile and the demographic and behavioral variables are described in methodology in the sample item.

The women with Aids of the sample prevailed those between 31 and 41 years old (47.7\%), whose average age was 38 years, standard deviation (SD) of 9.1 years, but $91.3 \%$ were productive and reproductive age group, brown (56.3\%), with over 4 years of study (73.1\%), with home activities (50.3\%), whose monthly income was up to 01 minimum wages (71,9\%), $63.8 \%$ reported being married; $39.6 \%$ were married at the time of the interview, or had already been (24.2\%), $96 \%$ belonged to the Christian religion, 53 \% were Catholic. Regarding to married life and gynecological - obstetric characteristics, prevailed women who lived with a partner 
(62.4\%), who gave birth at least 1 time (91.2 \%) and had at least one living child (88, $6 \%$ ). As for the lifestyle, the highlights were sedentary women (67.1\%), while $67.8 \%$ practiced up to a sexual relationship/month, who slept six hours or more a day (87.9\%), 72, $5 \%$ did not use drugs (tobacco and alcohol), $81.9 \%$ had steady sexual partner, $69.1 \%$ always wore condoms, and $57.7 \%$ practiced sexual activities satisfactory to themselves in more than $50 \%$ of their sexual activities (Table 4 ).

Evaluating Sexual Performance of the sample, the FSFI was layered in its domains. The mean, SD and the amplitude of each were observed, as well as its final score, in Table 6.

Table 6. Mean, standard deviation and range of domains and final score of the FSFI questionnaire for women with Aids. Imperatriz (MA)-BR. 2014.

\begin{tabular}{|l|c|c|}
\hline \multicolumn{1}{|c|}{ FSFI* domains } & Mean \pm SD & Amplitude \\
\hline Desire & $41.3 \pm 12.0$ & $12-60$ \\
\hline Arousal & $45.6 \pm 10.7$ & $12-60$ \\
\hline Lubrication & $46.1 \pm 11.9$ & $12-60$ \\
\hline Orgasm & $46.0 \pm 12.4$ & $12-60$ \\
\hline Satisfaction & $48.3 \pm 12.2$ & $12-60$ \\
\hline Pain & $41.7 \pm 12.3$ & $12-60$ \\
\hline FSFI & $265.7 \pm 54.0$ & $72-351$ \\
\hline & *: Female Sexual Function Index \\
\hline
\end{tabular}

It was observed that among the domains the highest average was satisfaction (48.3 \pm 12.2$)$, followed by lubrication and orgasm, and the lower averages were desire (41,3 \pm 12.0) and pain (41, $7 \pm 12.3)$ validating the cycle of sexual response according to(Basson, 2005).

To identify the $\mathrm{CD}^{+}$and CD8 T- lymphocyte count and CD4+/CD8 ratio, it was demonstrated average, standard deviation, median and range of $\mathrm{CD}^{+}$and CD8 T- lymphocyte counts, and CD4+/ CD8 ratio of the sample, in Table 7.
Table 7. Mean, standard deviation, median and amplitude of CD4+, CD8 T- lymphocytes count and CD4+/CD8 range of women with Aids . Imperatriz (MA), 2014.

\begin{tabular}{|l|c|c|c|}
\hline $\begin{array}{c}\text { Lymphocyte } \\
\text { count }\end{array}$ & Mean \pm SD & Median & Amplitude \\
\hline CD4 $^{+}$ & $545.3 \pm 289.5$ & 505.0 & $17-1429$ \\
\hline CD8 & $997.3 \pm 482.9$ & 895.0 & $181-3888$ \\
\hline CD4 $^{+} / C D 8$ & $0.6 \pm 0.4$ & 0.5 & $0.02-2.78$ \\
\hline
\end{tabular}

It was noted that there were women with extremely low $\mathrm{CD}^{+}{ }^{+}$counts, indicating a low immunity probably susceptible to infection, whereas others in the opposite situation.

Investigating the association between sexual performance and CD4 ${ }^{+} \mathrm{T}$ - lymphocyte count, first $\mathrm{CD}^{+}{ }^{+} \mathrm{T}$ - lymphocyte count was distributed into quartiles (lowest count for highest one), extracted the mean and standard deviation of these (Table 8), then these results were compared with the result of the FSFI questionnaire, also stratified into quartiles, and the median extracted from each quartile, using the Kruskal - Wallis test (Table 8). In this figure, it was observed that the lower $\mathrm{CD}^{+}{ }^{+}$count was in the first quartile, increasing in each quartile, finding the highest score above the third.

In Table 8 it can be seen that the highest average and median of the FSFI score showed up concurrently to highest average of $\mathrm{CD}^{+}$and the lowest averages of $\mathrm{CD}^{+}{ }^{+}$coincided with the lowest averages and medians of FSFI score (Kruskal Wallis test with $p=0,0347$ ).

The investigation of the association between sexual performance and the CD4+/CD8 ratio was conducted as shown in Table 9, using the Spearman correlation test, noting the existence of a positive association between $\mathrm{FSFI}$ and the $\mathrm{CD} 4^{+} / \mathrm{CD} 8$ ratio ( $p=0.0264)$, thus confirming the alternative hypothesis. 
Table 8. Association of the Female Sexual Function Index (FSFI) questionnaire score and CD4+-T lymphocyte count of women living with Aids, distributed in quartiles. Imperatriz (MA), 2014.

\begin{tabular}{|c|c|c|c|c|}
\hline \multicolumn{5}{|c|}{$\mathrm{CD}^{+}{ }^{+}-\mathrm{T}$ lymphocytes } \\
\hline $\mathrm{Mn} \pm \mathrm{SD}$ & $222.1 \pm 114.0$ & $438.4 \pm 43.7$ & $589.4 \pm 53.1$ & $940.1 \pm 205.6$ \\
\hline \multicolumn{5}{|l|}{ FSFI } \\
\hline$M n \pm S D$ & $247.4 \pm 58.6$ & $266.3 \pm 49.1$ & $265.8 \pm 62.1$ & $283.8 \pm 38.9$ \\
\hline Median & 252 & 280 & 284 & 295 \\
\hline$n(\%)$ & 38 (25.5) & $\begin{array}{c}\mathrm{Q}_{1} \\
37(24.5)\end{array}$ & $\begin{array}{c}\mathrm{Q}_{2} \\
37(24.5)\end{array}$ & $\begin{array}{c}\mathrm{Q}_{3} \\
37(24.5)\end{array}$ \\
\hline
\end{tabular}

Table 9. Spearman correlation between the score of the Female Sexual Function Index (FSFI) and $\mathrm{CD} 4^{+} / \mathrm{CD} 8$ range of women with Aids Imperatriz (MA)-BR., in 2014.

\begin{tabular}{|l|c|c|}
\hline \multirow{2}{*}{ T- Iymphocytes } & Mean \pm SD & Median \\
\cline { 2 - 3 } CD4 ${ }^{+} /$CD8 & Spearman & p-value \\
\hline
\end{tabular}

\section{Discussion}

Intersecting the information in (Hayashida et al., 2003)with the (Margolis, 2006), sexual activity,being a physical activity, can stimulate or inhibit immune function, depending on whether moderate or exhaustive respectively.

There is a strong association between physical activity and sexual function, as well as physical inactivity and sexual dysfunction (78.9\%) in inactive women compared to active ones (57.6\%) (Cabral et al., 2014). Corroborating these findings, (Margolis, 2006) and (Santos, 2010), has also considered that sexual activity is an important physical activity and can reduce sexual dysfunction, providing biopsychosocial wellness able to boost immunity. This study shows the practice of physical activity is not essential for satisfaction and good sexual performance, more than half of the women were sedentary and yet had had a positive and statistically significant association with good sexual performance.

The intimate relationships promote the proliferation of lymphocytes (Maia, 2002), and the positive interpersonal relationships are related to lower levels of stress hormones (cortisol and catecholamines), better immune system response, and decrease the risk of several types of infection (Mcguire e Kiecolt-Glaser, 2000 apud Maia, 2002). In this study, $99.3 \%$ of the surveyed women have sexual partnership; $81.9 \%$ stable and $17.4 \%$ not stable. Considering the above information and that during orgasm there is a release of oxytocin, neurohormone that promotes sexual receptivity, satisfaction, promoting positive interpersonal relationships(Crenshaw, 1998); (Keesling, 1998); (Komisaruk, 2006), sexual activity improves the immune response.

It is hoped that the knowledge is an effective tool for the prevention of STI's, but in this study the highest prevalence of Aids occurred in women with 5-12 years of school, the elementary school and high school periods, in which is taught basic knowledge of anatomy, physiology, relationship between living beings, some diseases resulting of these relationships, including STI's.

Some studies suggest a positive association between sexual activity and immunity in men and the reverse in women (Lorenz e Van Anders, 2014). This study, however, shows a positive association between sexual activity and CD4 ${ }^{+}$T- lymphocyte count by comparing the quartiles of the FSFI and $\mathrm{CD}^{+}{ }^{\text {, }}$ using the Kruskal-Wallis test, $\mathrm{p}=0.0347$, and and positive Spearman correlation between sexual activity and $\mathrm{CD} 4^{+} / \mathrm{CD} 8, \mathrm{p}=0.0264$.

PV Unprotected sexual intercourse is cited as the 
only one able to improve immunity(Brody, 2010); (Lajoie et al., 2014), but in this study only $11 \%$ of the sample surveyed did not use condoms, suggesting other factors related to sexual activity able to increase the $\mathrm{CD}_{4}{ }^{+} \mathrm{T}$ - lymphocyte count and $\mathrm{CD} 4^{+} /$ CD8. The study shows that sexual activity, consisting of desire, arousal, orgasm and satisfaction has a positive association with $\mathrm{CD}^{+} \mathrm{T}$ - lymphocyte.

\section{Conclusions}

In this study it was found that both physical and sexual activities may independently enhance immunity. Sexual satisfaction is important for the improvement of immunity. And in this sample there was a positive association between sex drive or sexual activity, with or without a condom, with $\mathrm{CD}^{+} \mathrm{T}$ - lymphocyte count and $\mathrm{CD} 4^{+} / \mathrm{CD} 8$ ratio.

\section{References}

- (OMS), O. M. D. S. Mulheres e Saúde: Evidências de hoje, agenda de amanhã. Suissa: Organização Mundial da Saúde, 2011. 112 ISBN 978-85-7967-059-6.

- (UNAids ), J. U. N. P. O. H. A. Global report: UNAids report on the global Aids epidemic 2012. 2012. ISSN 978-92-9173-592-1. Acesso em: 29/08/2014.

- Abbas, A. K. L.; Andrew, H.; Pillai, S., S. Imunologia celular e molecular. 7. Rio de Janeiro: Elsevier, 2011. 592 ISBN 978-85352-4744-2.

- Basson, R. Women's sexual dysfunction: revised and expanded definitions. CMAJ, v. 172(10), p. 7, 20052005.

- Bastos, F. I. A feminização da epidemia de aids no Brasil: determinantes estruturais e alternativas de enfrentamento. Rio de Janeiro, 2001. Acesso em: 30/08/2014.

- Brody, S. The relative health benefits of different sexual activities. J Sex Med, v. 7, n. 4 Pt 1, p. 1336-61, Apr 2010. Disponível em: $<$ http://www.ncbi.nlm.nih.gov/pubmed/20088868>.

- Cabral, P. U. et al. Physical activity and sexual function in middle-aged women. Rev Assoc Med Bras, v. 60, n. 1, p. 47-52, Jan-Feb 2014. Disponível em: <http://www.ncbi.nlm.nih.gov/ pubmed/24918852>

- Cavalcanti, R. C., M. Tratamento Clínico das Inadequações Sexuais. 4. São Paulo: Roca, 2012. 382 ISBN 978-85-4120-0097.

- Costeira, C. R. B. O. Toque na relação interpessoal - uma reflexão teórica sobre relações interpessoais. International
Journal of Developmental and Educational Psychology, v. 4, p. 325-330, 20082008.

- Crenshaw, T. L. A alquimia do amor e do tesão. Rio de Janeiro: Record, 1998. 445 ISBN 85-01-04835-6.

- Brasil, Departamento De DST, A. E. H. V. Aids. Brasília, Fevereiro 25, 2013 2013. Acesso em: 17/04/2013.

- Duarte, A. J. D. S. HIV/Aids . São Paulo: Editora Ateneu, 2010. 126 ISBN 978-85-388-0156-6.

- Faqueti, A. et al. Perfil epidemiológico de mortalidade por aids na população adulta do Brasil de 2001 a 2010. Rev. Saúde Públ. Santa Cat. Florianópolis. 7: 29- 39 p. 2014.

- Farthing, C. F.; BROWN, S.; STAUGHTON, R. C.D. Atlas colorido de Aids e da doença do HIV. 2. São Paulo: Artes Médicas, 1989. 114

- Gewehr, R. B.; Hetkowski, T. M. Sexo e sexualidade no mundo moderno. Contexto e Educação. Ijuí: UNIJUÍ. 64: 81 - 107 p. 2001.

- Ghosh, M.; Rodriguez-Garcia, M.; Wira, C. R. Immunobiology of genital tract trauma: endocrine regulation of HIV acquisition in women following sexual assault or genital tract mutilation. Am J Reprod Immunol, v. 69 Suppl 1, p. 51-60, Feb 2013. Disponível em: <http://www.ncbi.nlm.nih.gov/pubmed/23034063>.

- Hayashida, S. A. Y. et al. Endorfinas em Ginecologia. Revista Brasileira de Medicina. São Paulo: Moreira Jr: 8 - 15 p. 2003.

- Herbenick, D. et al. Prevalence and characteristics of vibrator use by women in the United States: Results from a nationally representative study. The journal of sexual medicine, v. 6, p. 1857-1866, 2009/7/1 2009. Acesso em: 05/01/2015.

- Imperatriz, Portal Da Prfeitura De Imperatriz. A Cidade: História e dados geográficos de Imperatriz. Disponível em http://www. imperatriz.ma.gov.br. Acesso em 03/01/2015

- Keesling, B. A Cura pelo Sexo. Rio de Janeiro: Record, 1998. 236 ISBN 85-01-04957-3.

- Komisaruk, B. R. B.-F., C. \& Whippple, B. The science of orgasm. United States of America: The Johns Hopkins University, 2006. 358 ISBN 0-8018-8490-x.

- Lajoie, J. et al. Association of sex work with reduced activation of the mucosal immune system. J Infect Dis, v. 210, n. 2, p. 31929, Jul 15 2014. Disponível em: <http://www.ncbi.nlm.nih.gov/ pubmed/24421257>

- Lorenz, T.; Van Anders, S. Interactions of sexual activity, gender, and depression with immunity. J Sex Med, v. 11, n. 4, p. 96679, Apr 2014. Disponível em: <http://www.ncbi.nlm.nih.gov/ pubmed/23448297>

- Maia, Â. Emoções e sistema imunológico: um olhar sobre a psiconeuroimunologia. Psicologia: teoria, investigação e prática. Portugal: Centro de Investigação em Psicologia. 2: 207-225 p. 2002.

- Margolis, J. A história íntima do orgasmo: tudo o que você nunca soube sobre os melhores 10 segundos de sua vida. Rio de Janeiro: Ediouro, 2006. 367 ISBN 85-00-01359-1.

- Markle, J. G.; Fish, E. N. . SeXX matters in immunity. Trends in immunology: Elsevier Current Trends. 35: 97-104 p. 2014 
- Marques, F. Z. C.; Chedid, S. B.; Eizerik, G. C. Resposta Sexual Humana. Rev. Ciênc. Méd. Campinas. 17: 175-183 p. 2008.

- Mattos, L. A.; Mahl, Á. C.; Silva, J. C.; Oliveira, L. A. A expressão fálica pelo olhar do mestre: considerações sobre a visão e trabalho dos educadores à respeito do comportamento sexual manifesto em seus alunos de três a cinco anos. Psicologia em Foco: Frederico Westphalen. 5: 77-91 p. 2013.

- Medeiros, S. F. M., A; Nince, A.P.B. Efeitos da terapia hormonal na menopausa sobre o sistema imune. Rev Bras Ginecol Obstet. 29: 593-601 p. 2007

- Pacagnella, R. C. M., E.Z.; Vieira, E.M. Validade de construto de uma versão em português do Female Sexual Function Index. Cad. saúde pública. São Paulo: SciELO Brasil. 25: 2333-2344 p. 2009.

- Pontes, Â. F. Sexualidade: vamos conversar sobre isso?Promoção do desenvolvimento psicossexual na adolescência: implementação e avaliação de um programa de intervenção em meio escolar. 2011. 282 Doutorado em ciências de saúde mental (Doutorado ). Instituto de Ciências Biomédicas Abel Salazar, Universidade do Porto Portugal.

- Rohde, G. et al. Perceived effects of health status on sexual activity in women and men older than 50 years. Health and quality of life outcomes, v. 12, p. 43, 20142014

- Roitt, I. M.; Brostoff, J.; Male, D. Imunologia. São Paulo: Manole, 1989. 312

- Rosen, R. et al. The Female Sexual Function Index (FSFI): a multidimensional self-report instrument for the assessment of female sexual function. J Sex Marital Ther, v. 26, n. 2, p. 191208, Apr-Jun 2000. Disponível em: <http://www.ncbi.nlm.nih. gov/pubmed/10782451>.

- Santos, V. C.; Santos, A.C. Exercício Físico e Seus Efeitos Sobre o Sistema Imune dos Idosos. Saúde e Pesquisa: Saúde e Pesquisa. 3: $181-185$ p. 2010

- Sena, T. Os relatórios de Masters \& Johnson: gênero e as práticas psicoterapêuticas sexuais a partir \{Roitt, 1989 \#73\}da década de 70. Estudos Feministas. Florianópolis: Estudos Feministas. 18: 221-239 p. 2010.

- Sena, T.; Lago, M. C. S.; Grossi, M. P. Os relatórios Kinsey, Masters \& Johnson, Hite: sexualidades, estatísticas e normalidades configurando a Persona Numerabilis. 2012. 20 Doutorado em Ciências Humanas (Doutorado ). Programa de Pós-graduação Interdisciplinar em Ciências Humanas da UFSC, UFSC, Florianópolis.
- Silva, C. M. ¡Vargens, O. M. C. A percepção de mulheres quanto à vulnerabilidade feminina para contrair DST/HIV. Rev esc enferm USP. USP: Rev. Esc. Enferm. USP. 43: 401-6 p. 2009.

- Soares, R.; Armindo, R. D.; Rocha, G. A imunodeficiência e o sistema imunitário. O comportamento em portadores de HIV. Arq Med. Porto: <http://www.scielo.mec.pt/scielo. php?script=sci arttext\&pid=S0871-34132014000400004\&Ing $=$ pt\&nrm=iso>. 282014

- UNESCO. Razões em Favor da Educação em Sexualidade: Orientação Técnica Internacional sobre Educação em Sexualidade. Uma abordagem baseada em evidências para escolas, professores e educadores em saúde. Orientação Técnica Internacional sobre Educação em Sexualidade. Brasília: UNESCO. 1: 129 p. 2010.

- Vitiello, N.; Junior, O. M. R. As bases anatômicas e funcionais do exercício da sexualidade. São Paulo: Iglu, 1997. 180

- Zampieri, A. M. F. Erotismo, sexualidade, casamento e infidelidade: Sexualidade conjugal e prevenção do HIV e da Aids. São Paulo: Ágora, 2004. 245 ISBN 85-7183-871-2.
Publish in International Archives of Medicine

International Archives of Medicine is an open access journal publishing articles encompassing all aspects of medical science and clinical practice. IAM is considered a megajournal with independent sections on all areas of medicine. IAM is a really international journal with authors and board members from all around the world. The journal is widely indexed and classified Q1 in category Medicine. 